\title{
Research Article \\ Efficacy Comparison of Various Repair Techniques for Flexor Tendon Injuries: A Systematic Review and Meta-Analysis
}

\author{
Anak Agung Gde Duta Maha Putra ${ }^{1}$, Made Bramantya Karna ${ }^{1}$ D , Anak Agung Gde Yuda Asmara ${ }^{1}$, \\ Putu Feryawan Meregawa ${ }^{1}$ iD \\ ${ }^{1}$ Department of Orthopaedic and Traumatology Sanglah Hospital/ Universitas Udayana, Denpasar, Indonesia
}

Correspondence should be addressed to Anak Agung Gde Duta Maha Putra, Department of Orthopaedic and Traumatology Sanglah Hospital/ Universitas Udayana, J1. Diponegoro, Dauh Puri Klod, Denpasar 80113, Indonesia. e-mail: agungduta08@gmail.com

\begin{abstract}
Background: Flexor tendon injuries are potentially disabling, as flexor tendons are essential to hand function, playing a vital role in all types of grip, including power grip and fine pinch grip. However, there has been no consensus regarding the most effective repair technique for this pathology.

Methods: A systematic search was conducted based on PRISMA guidelines to identify relevant studies through PubMed, Google Scholar, and Cochrane. A total of 9 studies (266 tendons from 108 patients) were included.

Results: In comparison between Modified Kessler and Four-stranded Cruciate technique, Fourstranded Cruciate Suture produces higher $2 \mathrm{~mm}$ gap strength $(\mathrm{I} 2=93 \%, \mathrm{P}<0.00001)$, higher ultimate strength $(\mathrm{I} 2=99 \%, \mathrm{P}=0.02)$, and better Functional Outcome as measured by Strickland Criteria (I2=0\%, P<0.0001). In comparison between the 2-Stranded and the 4-Stranded Kessler technique. The 4-Stranded Kessler technique produces higher $2 \mathrm{~mm}$ gap strength (I2=98\%, $\mathrm{P}=0.02)$ and higher ultimate strength $(\mathrm{I} 2=60 \%, \mathrm{P}<0.00001)$.

Conclusion: Current systematic review and meta-analysis suggest that the 4-stranded cruciate repair technique has better strength and functional outcome than the modified Kessler, especially in zone II and III injuries. Four-stranded Kessler is also proven to have better strength compared to the two-stranded Kessler.
\end{abstract}

Keywords: Biomechanics; Cruciate; Flexor tendon; Kessler; Tendon repair; Human and Medicine

\section{INTRODUCTION}

Flexor tendons are essential to hand function, playing a vital role in all grip types, including power grip and fine pinch grip. The studies of flexor tendon injuries showing a $7 \%$ occurrence in hand injuries. ${ }^{1}$ Flexor tendon injuries frequently occur through division in deep lacerations of the fingers, palm, or forearm. ${ }^{2}$ Flexor tendon injuries commonly occur in young, active people. ${ }^{3,4}$ Several approaches to flexor tendon injury had 70-90\% of successful repair rates. ${ }^{5}$ The most common mechanism of finger flexor tendon disruptions reported in children is cut by glass. ${ }^{6}$ Superior function obtained in the repair of sharply incised tendons instead of crushing injuries is a well-known fact. $^{7}$

Flexor tendon injuries of the hand are commonly encountered problem, affecting both gender and different age groups due to varying 
types of injurious agents, sometimes associated with fractures of phalanges and/or nerve or vessel injuries that could result in significant functional disabilities that have a negative impact on working ability and lifestyle. ${ }^{2}$

Flexor tendon injuries are commonly encountered and the surgical repair still represents a challenging problem. According to Strickland, the characteristics of an ideal primary flexor tendon repair are easily placed in tendon, secure knots, smooth junctions, minimal gapping, minimal interference with tendon vascularity, and sufficient strength throughout healing to permit application of early motion stress. ${ }^{8}$ Re-establishing normal hand and wrist function with a normal range of finger and wrist movement and normal grip strength remains one of the most difficult goals to achieve. Furthermore, tendon repair complications like tendon rupture, gapping, adhesions, and joint stiffness are influenced by factors, including age, mechanism, level of injury, repair technique, and the rehabilitation protocol. ${ }^{6,9,10}$

As far as we observe, there has not been any meta-analysis to objectively compare the repair strength and outcomes of some commonly used repair techniques (Modified Kessler vs. Four-stranded Cruciate technique and Two-stranded Kessler vs. Four-stranded Kessler Technique).

\section{MATERIAL AND METHODS}

The study design was a systematic review and meta-analysis over numbers of randomized controlled trials and non-randomized comparative studies. A systematic search was conducted to identify relevant studies up to the 2020 publication year through PubMed, Google Scholar, and Cochrane database based on PRISMA guidelines (Figure 1). The keywords used were:

- "Modified Kessler" AND "Cruciate" AND "Flexor Tendon" AND "Strength"

- "Modified Kessler" AND "Cruciate” AND "Flexor Tendon" AND "Outcome"

- "Two-stranded Kessler" AND "Fourstranded Kessler" AND "Flexor Tendon" AND "Strength"

Those data were then manually scanned and reviewed by authors with the inclusion criteria: (1) the studies included a comparative design for the modified Kessler vs. Cruciate repair and Two-stranded Kessler vs. Four-stranded Kessler, (2) Outcomes discussed are repair strength $(2 \mathrm{~mm}$ gap and ultimate strength) and functional outcome based on Strickland Criteria. Exclusion criteria were crush injuries, lack of adequate skin cover, a concomitant fracture or chondral lesion, replantation, extensor tendon injury in the same digit, and previous hand trauma. Table 1 describes the PICO method for defining the inclusion and exclusion criteria. 

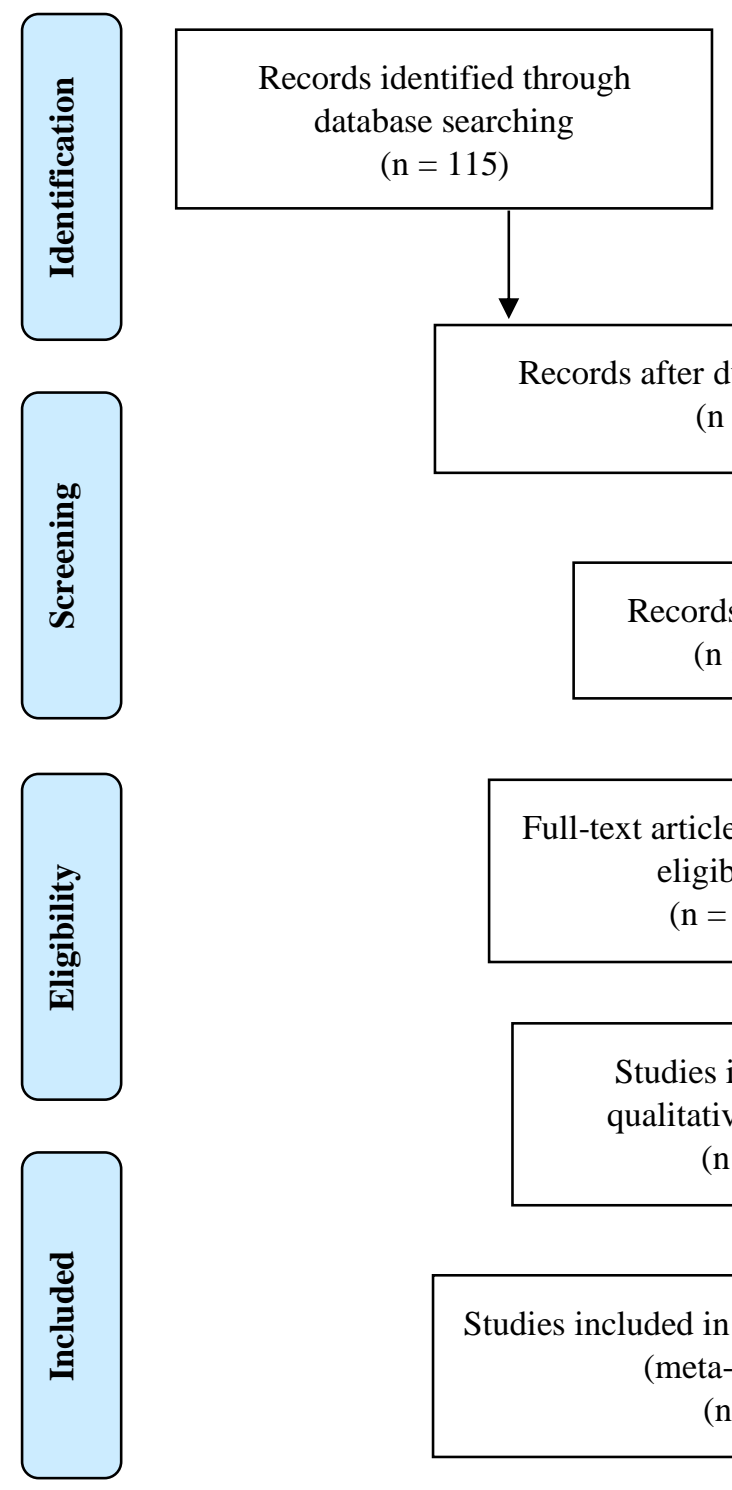
Additional records identified through other sources $(\mathrm{n}=0)$
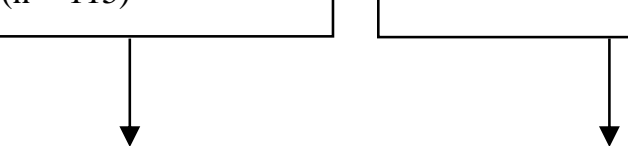

Records after duplicates removed $(\mathrm{n}=96)$

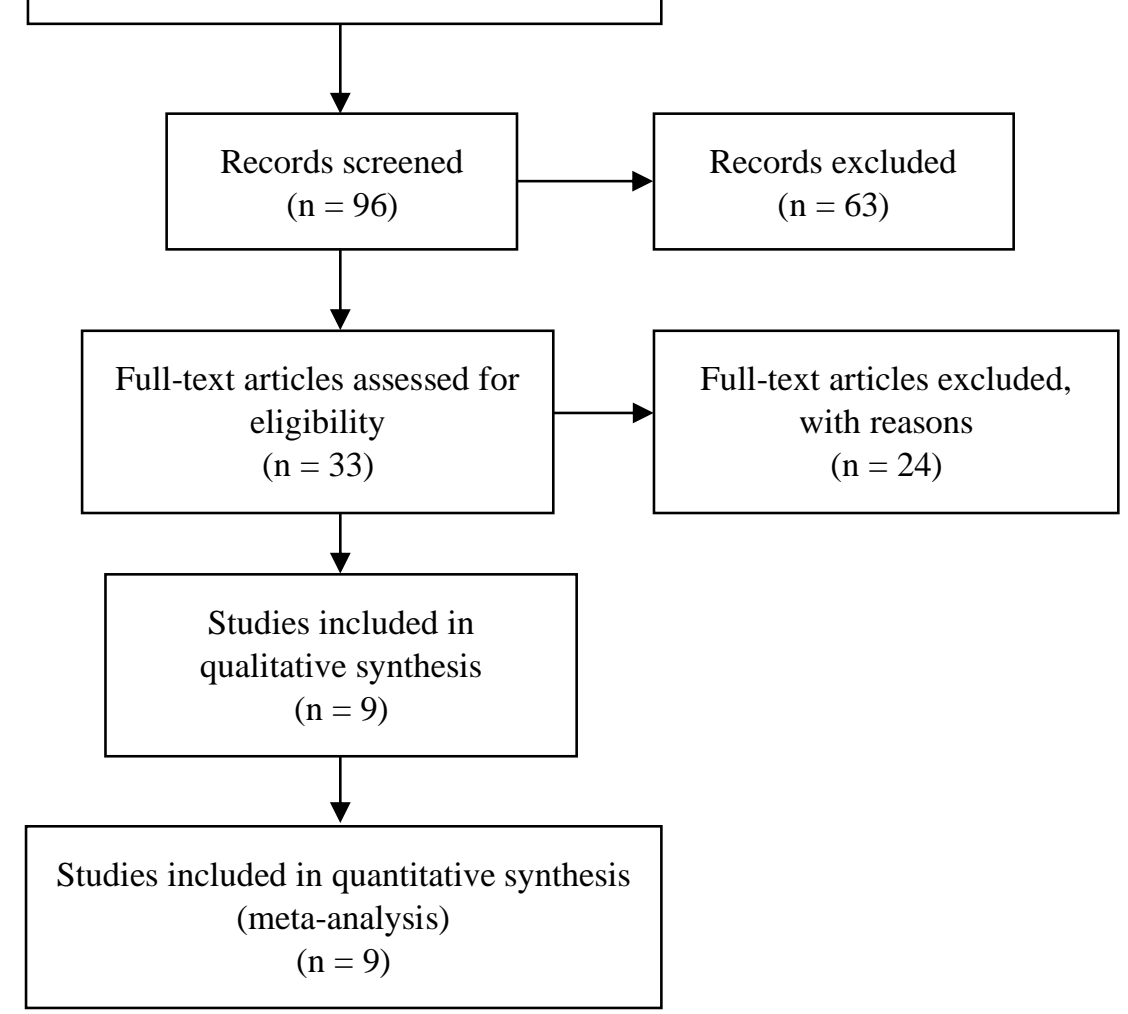

Figure 1. Flow chart showing article selection 
Table 1. PICO Table Describing Inclusion and Exclusion Criteria

\begin{tabular}{|c|c|c|}
\hline $\begin{array}{c}\text { Study } \\
\text { Component }\end{array}$ & Inclusion & Exclusion \\
\hline Population & $\begin{array}{l}\text { - Any age } \\
\text { - Any sex } \\
\text { - Human or animal studies } \\
\text { - In vivo or in vitro studies } \\
\text { - Injury in flexor tendons }\end{array}$ & $\begin{array}{l}\text { - Crush injuries, lack of adequate skin cover, } \\
\text { - A concomitant fracture or chondral lesion, } \\
\text { replantation, and extensor tendon injury in the } \\
\text { same digit, } \\
\text { - Previous hand trauma }\end{array}$ \\
\hline Intervention & - Modified Kessler vs. Four-stranded & - Other methods of treatment \\
\hline $\begin{array}{l}\text { and } \\
\text { Comparison }\end{array}$ & $\begin{array}{l}\text { Cruciate } \\
\text { - Two-stranded Kessler vs. Four- } \\
\text { stranded Kessler }\end{array}$ & $\begin{array}{l}\text { - Studies with only one method of treatment (non- } \\
\text { comparative studies) }\end{array}$ \\
\hline Outcome & $\begin{array}{l}\text { - } 2 \text { mm gap strength } \\
\text { - Ultimate strength } \\
\text { - Functional outcome based on } \\
\text { Strickland Criteria }\end{array}$ & No outcome mentioned or different outcomes \\
\hline Publication & $\begin{array}{l}\text { - Studies published in English in } \\
\text { peer-reviewed journals }\end{array}$ & $\begin{array}{l}\text { - Duplicate publications of the same study that do } \\
\text { not report on different outcomes } \\
\text { - Meeting presentations or proceedings }\end{array}$ \\
\hline Study Design & $\begin{array}{l}\text { - Randomized controlled trials and } \\
\text { non-randomized comparative } \\
\text { studies }\end{array}$ & $\begin{array}{l}\text { - Review articles } \\
\text { - Abstracts, editorials, letters } \\
\text { - Case reports }\end{array}$ \\
\hline
\end{tabular}

Abbreviations: PICO, Population-Intervention-Comparison-Outcome

The data extraction was collected under basic characteristics, and the main outcomes presented the final functional outcome and biomechanical outcome. In each study, the mean difference (MD) for continuous outcome and odds ratio (OR) for dichotomous outcome with a 95\% confidence interval (CI) was calculated using Review Manager (RevMan) [Computer program, Version 5.3. Copenhagen: The Nordic Cochrane Centre, the Cochrane Collaboration, 2014]. Fixed effect model was used when the heterogeneity was $<50 \%$, whereas random effect model was used when the heterogeneity was $>50 \%$.

\section{RESULTS}

A total of nine studies (266 tendons from 108 patients) were included, divided into five metaanalyses. Nine studies are Prospective Randomized Controlled Trial (Level I evidence) (Table 2).

A study was to develop and test in vitro a new flexor tendon suture technique repaired using 1 of 4 suture techniques (the modified Kessler, the Strickland, the modified 4-strand Savage Cruciate 4-strand repairs). Each repair was tested using a slow-test machine and displacement control at two $\mathrm{mm} / \mathrm{s}$. Force applied, the resultant gap and ultimate tensile strength were recorded, and statistical comparisons were 
Table 2. Studies included in the analysis

\begin{tabular}{|c|c|c|c|c|}
\hline No. & Reference & Journal & Study Design & $\begin{array}{l}\text { Level of } \\
\text { Evidence }\end{array}$ \\
\hline 1. & $\begin{array}{l}\text { McLarney et al. } \\
\text { (1999) }\end{array}$ & The Journal of Hand Surgery & $\begin{array}{l}\text { Randomized Controlled } \\
\text { Trial (Cadavers) }\end{array}$ & I \\
\hline 2. & Barrie et al. (2000) & The Journal of Hand Surgery & $\begin{array}{l}\text { Randomized Controlled } \\
\text { Trial (Cadavers) }\end{array}$ & I \\
\hline 3. & Tang et al. (2001) & $\begin{array}{l}\text { Plastic and Reconstructive } \\
\text { Surgery }\end{array}$ & $\begin{array}{l}\text { Randomized Controlled } \\
\text { Trial (Cadavers) }\end{array}$ & I \\
\hline 4. & $\begin{array}{l}\text { Waitayawinyu et al. } \\
\text { (2008) }\end{array}$ & The Journal of Hand Surgery & $\begin{array}{l}\text { Randomized Controlled } \\
\text { Trial (Cadavers) }\end{array}$ & I \\
\hline 5 . & Navali et al. (2008) & The Journal of Hand Surgery & $\begin{array}{l}\text { Randomized Controlled } \\
\text { Trial (Humans) }\end{array}$ & I \\
\hline 6. & Shaikh et al. (2018) & $\begin{array}{l}\text { Surgical Medicine Open Access } \\
\text { Journal }\end{array}$ & $\begin{array}{l}\text { Randomized Controlled } \\
\text { Trial (Humans) }\end{array}$ & I \\
\hline 7. & $\begin{array}{l}\text { Karjalainen et al. } \\
\text { (2012) }\end{array}$ & The Journal of Hand Surgery & $\begin{array}{l}\text { Randomized Controlled } \\
\text { Trial (Cadavers) }\end{array}$ & I \\
\hline 8. & $\begin{array}{l}\text { Dogramaci et al. } \\
\text { (2008) }\end{array}$ & HAND & $\begin{array}{l}\text { Randomized } \\
\text { Trial (Sheep) }\end{array}$ & I \\
\hline 9. & Yalcin et al. (2011) & $\begin{array}{l}\text { Acta Orthopaedica et } \\
\text { Traumatologica Turcica }\end{array}$ & $\begin{array}{l}\text { Randomized Controlled } \\
\text { Trial (Cadavers) }\end{array}$ & I \\
\hline
\end{tabular}

performed using a two-tailed Student's t-test with the level of significance set at p 5.05.

In another study, functional outcome was better in 4 strands cruciate repair with excellent result in $66.6 \%$, good in $29.1 \%$ and fair in $4.1 \%$, as compared to modified Kessler technique in which excellent results were found in $45.8 \%$, good in $37.5 \%$, fair in $12.5 \%$ and poor in $4.1 \%$ of cases. A better functional result was achieved in 4 strands cruciate repair, especially in zone II, with excellent results in $33.3 \%$, good in $50 \%$, and fair in $16.6 \%$ of cases, as compared to modified Kessler repair with no excellent results, $33.3 \%$ good, $50 \%$ fair and $16.6 \%$ poor results.

Another study, implemented repairs on 40 flexor digitorum profundus (FDP) tendons acquired from fresh frozen cadavers. The tendons were divided into five groups of 8 tendons each. The 2-strand modified Kessler suture technique was used in the first group, the 4-strand Strickland suture technique in the second group, the 4-strand modified Kessler (without epitenon suture) suture technique in the third group, and the 4-strand modified Kessler (with epitenon sutures) suture technique in the fourth group. The remaining eight intact tendons were set aside as the control group. The ultimate tensile strength of the 2strand modified Kessler group was determined as $39.89 \pm 9.65$ Newtons $(\mathrm{N})$, the ultimate tensile strength of the 4-strand Strickland group was $39.64 \pm 9.14 \mathrm{~N}$, the ultimate tensile strength of 4strand modified Kessler group (without epitenon suture) was $50.29 \pm 11.24 \mathrm{~N}$, the ultimate tensile strength of 4-strand modified Kessler group (with epitenon suture) was $54.47 \pm 6.83 \mathrm{~N}$, and the ultimate tensile strength of the control group was $119 \pm 17.59 \mathrm{~N}$. 
Table 3. Studies included in the analysis

\begin{tabular}{|c|c|c|c|c|c|c|c|c|}
\hline \multirow[b]{2}{*}{ No. } & \multirow[b]{2}{*}{ Reference } & \multicolumn{3}{|c|}{ Patient Characteristics } & \multirow[b]{2}{*}{ Injury Site/Zone } & \multicolumn{2}{|c|}{$\begin{array}{c}\text { Duration of Surgery } \\
\text { (minutes) }\end{array}$} & \multirow[b]{2}{*}{$\begin{array}{l}\text { Follow Up } \\
\text { Period }\end{array}$} \\
\hline & & Sample Size & Age (years) & Sex & & $\begin{array}{l}\text { Modified } \\
\text { Kessler }\end{array}$ & $\begin{array}{c}\text { Four- } \\
\text { Stranded } \\
\text { Cruciate }\end{array}$ & \\
\hline 1 & $\begin{array}{l}\text { McLarney et } \\
\text { al. (1999) }\end{array}$ & $\begin{array}{l}20 \text { tendons from } 14 \\
\text { cadavers: } \\
\text { Kessler: } 10 \\
\text { Cruciate: } 10\end{array}$ & NA & NA & $\begin{array}{l}\text { Index, long, and ring finger } \\
\text { flexor profundus tendons }\end{array}$ & $3 \pm 0.5$ & $4 \pm 1$ & NA \\
\hline 2 & $\begin{array}{l}\text { Barrie et al. } \\
\quad(2000)\end{array}$ & $\begin{array}{l}20 \text { tendons from } 21 \\
\text { cadavers: } \\
\text { Kessler: } 10 \\
\text { Cruciate: } 10\end{array}$ & NA & NA & $\begin{array}{l}\text { Index, long, and ring finger } \\
\text { flexor profundus tendons }\end{array}$ & NA & NA & NA \\
\hline 3 & $\begin{array}{l}\text { Tang et al. } \\
\text { (2001) }\end{array}$ & $\begin{array}{l}\text { Kessler: } 10 \\
\text { Cruciate: } 10\end{array}$ & NA & NA & NA & $6.2 \pm 0.5$ & $9.0 \pm 0.5$ & NA \\
\hline 4 & $\begin{array}{l}\text { Waitayawinyu } \\
\text { et al. (2008) }\end{array}$ & $\begin{array}{l}\text { Kessler: } 7 \\
\text { Cruciate: } 7\end{array}$ & $72(54-91)$ & NA & NA & NA & NA & NA \\
\hline 5 & $\begin{array}{l}\text { Navali et al. } \\
\qquad(2008)\end{array}$ & $\begin{array}{l}32 \text { tendons in } 29 \\
\text { patients: } \\
\text { Kessler: } 16 \\
\text { Cruciate: } 16\end{array}$ & $\begin{array}{l}34 \text { months } \\
\text { (11-46 months) }\end{array}$ & NA & Zone 2 FDP lacerations & NA & NA & $\begin{array}{l}11 \text { months } \\
\text { (8-18 } \\
\text { months) }\end{array}$ \\
\hline 6. & $\begin{array}{l}\text { Shaikh et al. } \\
\text { (2018) }\end{array}$ & $\begin{array}{l}140 \text { tendons in } 44 \\
\text { patients. } \\
\text { Kessler: } 70 \\
\text { Cruciate: } 70\end{array}$ & $28.05 \pm 10.42$ & $\begin{array}{l}\text { M: } 28(63.64 \%) \\
F: 16(36.36 \%)\end{array}$ & $\begin{array}{l}\text { Thumb: } 8(5.7 \%) \\
\text { Index finger: } 24(17.1 \%) \\
\text { Middle finger: } 44(31.4 \%) \\
\text { Ring finger: } 42(30 \%) \\
\text { Little finger: } 22(15.7 \%)\end{array}$ & NA & NA & 8 weeks \\
\hline 7. & $\begin{array}{l}\text { Karjalainen et } \\
\text { al. (2012) }\end{array}$ & $\begin{array}{l}\text { Kessler: } 10 \\
\text { Cruciate: } 10\end{array}$ & NA & NA & $\begin{array}{l}\text { Flexor digitorum profundus } \\
\text { tendons from the index, } \\
\text { middle, and ring fingers }\end{array}$ & NA & NA & NA \\
\hline
\end{tabular}


Table 4. Modified Kessler vs. Four Stranded Cruciate

\begin{tabular}{|c|c|c|c|c|c|}
\hline \multirow{2}{*}{ No. } & \multirow{2}{*}{ Reference } & \multicolumn{2}{|c|}{ Tensile Strength } & \multicolumn{2}{|c|}{ Functional Outcome } \\
\hline & & Modified Kessler & Four-Stranded Cruciate & Modified Kessler & Four-Stranded Cruciate \\
\hline 1 & $\begin{array}{l}\text { McLarney et al. } \\
\text { (1999) }\end{array}$ & $\begin{array}{l}2 \text { mm gap: } 22 \pm 3.5 \\
\text { Ultimate: } 28 \pm 2.8\end{array}$ & $\begin{array}{l}2 \text { mm gap: } 44 \pm 4 \\
\text { Ultimate: } 55 \pm 3.1\end{array}$ & NA & NA \\
\hline 2 & $\begin{array}{l}\text { Barrie et al. } \\
\qquad(2000)\end{array}$ & $\begin{array}{l}2 \mathrm{~mm} \text { gap: } 14 \pm 2 \\
\text { Ultimate: } 39 \pm 6 \\
\text { 2mm gap: } 21.2 \pm 4.0\end{array}$ & $\begin{array}{l}2 \mathrm{~mm} \text { gap: } 37 \pm 2.3 \\
\text { Ultimate: } 70 \pm 8 \\
\text { 2mm gap: } 37.4 \pm 3.8\end{array}$ & NA & NA \\
\hline 3 & Tang et al. (2001) & $\begin{array}{l}\text { Ultimate: } 24.7 \pm 3.0 \\
\text { Elastic modulus: } 3.1 \pm 0.3 \\
\text { Energy to failure: } 0.09 \pm 0.02\end{array}$ & $\begin{array}{l}\text { Ultimate: } 46.3 \pm 3.8 \\
\text { Energy to failure: } 4.5 \pm 0.3 \\
\text { Energy to failure: } 0.26 \pm 0.04\end{array}$ & NA & NA \\
\hline 4 & $\begin{array}{l}\text { Waitayawinyu et } \\
\text { al. (2008) }\end{array}$ & $\begin{array}{l}\text { 2mm gap: } 39 \pm 12 \\
\text { Ultimate: } 56 \pm 6\end{array}$ & $\begin{array}{l}\text { 2mm gap: } 96 \pm 12 \\
\text { Ultimate: } 107 \pm 12\end{array}$ & NA & NA \\
\hline 5 & $\begin{array}{l}\text { Navali et al. } \\
\quad(2008)\end{array}$ & - NA & - NA & $\begin{array}{l}\text { - Satisfactory: } 14(87.5 \%) \\
\text { - Fair: } 2(12.5 \%)\end{array}$ & $\begin{array}{l}\text { - Satisfactory: } 15(93.75 \%) \\
\text { - Fair: } 1(6.25 \%)\end{array}$ \\
\hline 6. & $\begin{array}{l}\text { Shaikh et al. } \\
\text { (2018) }\end{array}$ & - NA & - NA & $\begin{array}{l}\text { - Satisfactory: } 20(28.6 \%) \\
\text { - Fair: } 50(71.4 \%)\end{array}$ & $\begin{array}{l}\text { - Satisfactory: } 46(65.7 \%) \\
\text { - Fair: } 24(34.3 \%)\end{array}$ \\
\hline 7. & $\begin{array}{c}\text { Karjalainen et al. } \\
\text { (2012) }\end{array}$ & $\begin{array}{ll}\text { - Stiffness: } 7 \pm 3 \\
\text { - Ultimate: } 39 \pm 6\end{array}$ & $\begin{array}{l}\text { - Stiffness: } 2.75 \pm 1.2 \\
\text { - Ultimate: } 20 \pm 3\end{array}$ & - NA & - NA \\
\hline
\end{tabular}

Abbreviations: NA, Not Available.

Table 5. 2-Stranded Kessler vs. 4-Stranded Kessler

\begin{tabular}{|c|c|c|c|c|c|}
\hline \multirow[t]{2}{*}{ No. } & \multirow[t]{2}{*}{ Reference } & \multirow[t]{2}{*}{ Sample Size } & \multirow[t]{2}{*}{ Injury Site/Zone } & \multicolumn{2}{|c|}{ Tensile Strength } \\
\hline & & & & 2-Strand Kessler & 4-Strand Kessler \\
\hline 1 & Barrie et al. (2000) & $\begin{array}{l}20 \text { tendons from } 21 \\
\text { cadavers: } \\
\text { 2-Kessler: } 10 \\
\text { 4-Kessler: } 10\end{array}$ & $\begin{array}{l}\text { Index, long, and ring finger } \\
\text { flexor profundus tendons }\end{array}$ & $\begin{array}{l}2 \text { mm gap: } 14 \pm 2 \\
\text { Ultimate: } 39 \pm 6\end{array}$ & $\begin{array}{l}2 \mathrm{~mm} \text { gap: } 26 \pm 2 \\
\text { Ultimate: } 66 \pm 11\end{array}$ \\
\hline 2 & $\begin{array}{l}\text { Dogramaci et al. } \\
(2008)\end{array}$ & $\begin{array}{l}20 \text { tendons: } \\
\text { 2-Kessler: } 10 \\
\text { 4-Kessler: } 10\end{array}$ & $\begin{array}{l}\text { Flexor digitorum profundus } \\
\text { tendons of forelimbs }\end{array}$ & $\begin{array}{l}2 \text { mm gap: } 22.56 \pm 3.44 \\
\text { Ultimate: } 34.44 \pm 2.33\end{array}$ & $\begin{array}{l}2 \mathrm{~mm} \text { gap: } 30.85 \pm 1.9 \\
\text { Ultimate: } 53.38 \pm 8.09\end{array}$ \\
\hline 3 & Yalcin et al. (2011) & $\begin{array}{l}16 \text { tendons from } 7 \\
\text { cadavers: } \\
\text { 2-Kessler: } 8 \\
\text { 4-Kessler: } 8\end{array}$ & $\begin{array}{l}\text { Index, middle, and ring fingers } \\
\text { of } 14 \text { hands }\end{array}$ & Ultimate: $39.89 \pm 9.65$ & Ultimate: $54.47 \pm 6.83$ \\
\hline
\end{tabular}




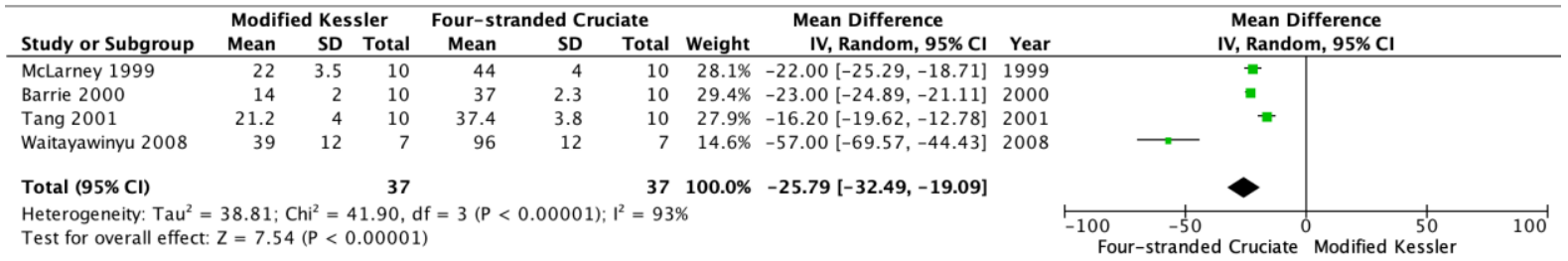

A

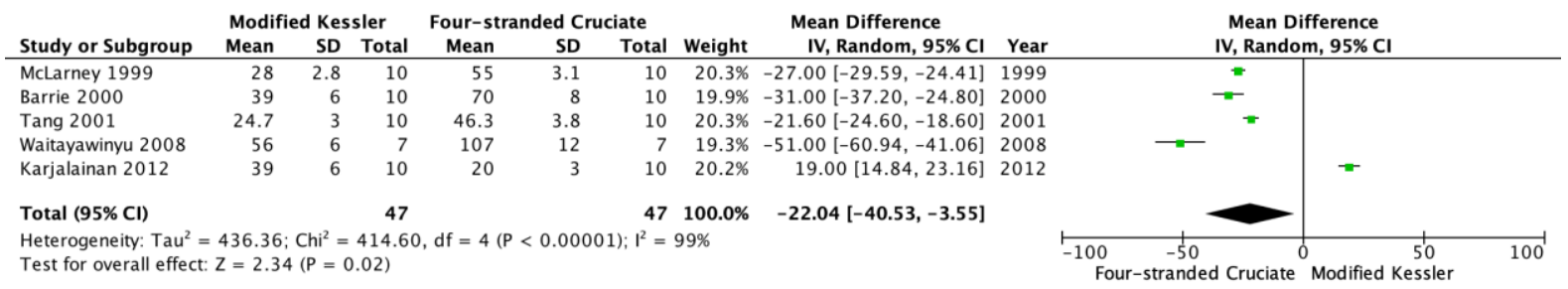

B

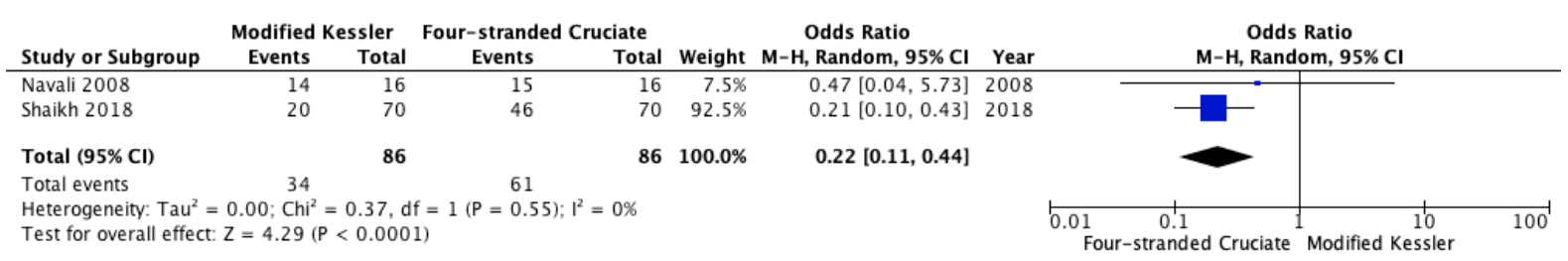

$\mathbf{C}$

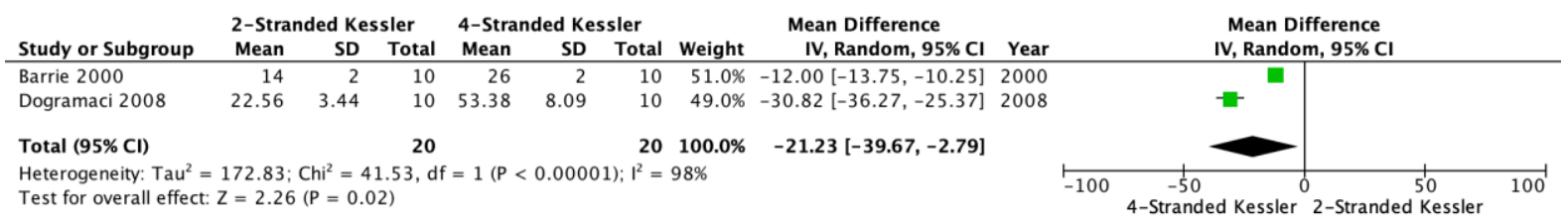

D

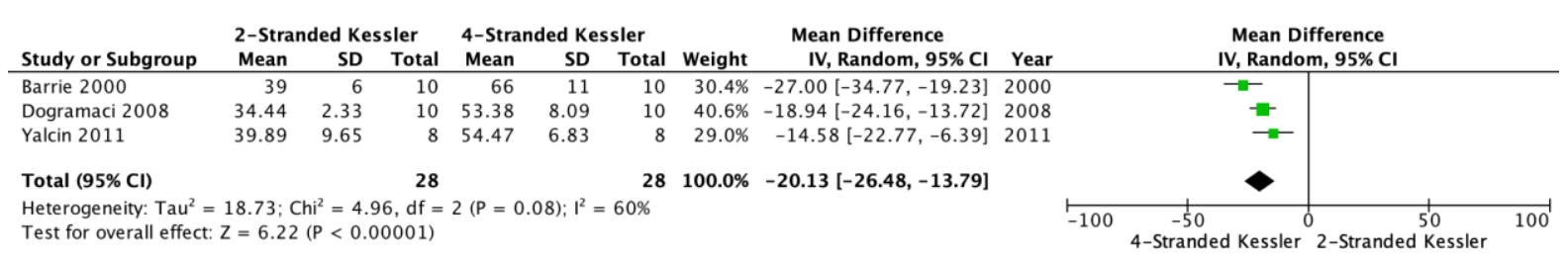

$\mathbf{E}$

Figure 2. Forest Plot for $2 \mathrm{~mm}$ Gap Strength (A), Forest Plot for Ultimate Strength (B), Forest Plot for Functional Outcome (C), Forest Plot for $2 \mathrm{~mm}$ Gap Strength (D), Forest Plot for Ultimate Strength (E)

In zone III, 4 strand cruciate technique showed a better functional outcome with $77.7 \%$ excellent and $22.2 \%$ good results compared to $55.5 \%$ excellent and $44.4 \%$ good results found in Modified Kessler repair. Zone V showed almost comparable results between the two types of repairs.

The tensile strength of 4-strand modified Kessler group (with epitenon suture) group was significantly higher $(\mathrm{p}<0.05)$ than 2 strand modified Kessler group. The tensile 
strength of the 4-strand modified Kessler group (without epitenon suture) was also significantly higher $(\mathrm{p}<0.05)$ than 2-strand modified Kessler group. No significant difference was observed between the tensile strengths of the 2-strand modified Kessler and 4-strand Strickland group $(p>0.05)$.

In comparison between Modified Kessler and Four-stranded Cruciate technique, Four-stranded Cruciate Suture produces higher $2 \mathrm{~mm}$ gap strength (4 studies with 74 samples, $\left.I^{2}=93 \%, P<0.00001\right)$, higher ultimate strength (5 studies with 94 samples, $\mathrm{I}^{2}=99 \%, \mathrm{P}=0.02$ ), and better Functional Outcome as measured by Strickland Criteria (2 studies with 172 samples, $\left.\mathrm{I}^{2}=0 \%, \mathrm{P}<0.0001\right)$.

\section{DISCUSSION}

The flexor tendons are strong, smooth cords that connect the forearm muscles to the bones in the fingers and thumb. There are two to each finger and one for the thumb. Tendons run inside tunnels at the wrist and in the fingers, and they bend the fingers in the manner of a bicycle brake cable. Tendons can be damaged by any cut across the wrist or hand's palmar surface, especially at the finger creases where the tendons lie just under the skin. Occasionally, the tendon is detached from the bone by a violent pulling injury to the finger. Each hand's specific movement relies on the finely tuned biomechanical interplay of the intrinsic and extrinsic musculotendinous forces. ${ }^{11,12}$

Flexor tendon injuries commonly occur in young, active people. The most common mechanism of finger flexor tendon disruptions reported in children is cut by glass. Superior function obtained in the repair of sharply incised tendons as opposed to crushing injuries is well-known. Restoring digital function after a flexor tendon injury continues to be one of the greatest challenges in the field of hand surgery. ${ }^{13}$ Advances in the understanding of tendon anatomy, nutrition, healing, and postoperative rehabilitation have generated an evolution of techniques that have enhanced the results of flexor tendon repair. ${ }^{14}$ The surgical repair technique for zone two flexor tendon injuries has been debated extensively through the years, but adhesion formation, suture rupture, and suture locking on the pulley edge remain possible consequences of a poor repair. Although increasing the repair strength through increasing the number of strands crossing the repair site to allow active postoperative mobilization without increasing the risk of rupture is logical, it can compromise tendon gliding function.

The cruciate suture technique was nearly twice as strong as $2 \mathrm{~mm}$ gap formation compared with the Kessler, Strickland, and Savage repairs. Ultimate tensile strength was also significantly stronger for the Cruciate technique than the Kessler, Strickland, or Savage repairs. The technique was significantly faster to perform than the Savage or Strickland repairs and was comparable in repair time to the 2-stranded Kessler repair. The new suture technique's design allowed the tendon repair to be completed with the ease and speed of a 2strand technique but bestowed on the repair strength that exceeded current 4-strand 
techniques. Besides that, the tensile strength of 4-strand sutures, with or without epitenon sutures, is significantly higher than the tensile strength of 2-strand sutures. All suture techniques applied had sufficient tensile strength to promote early mobilization. ${ }^{14,15}$ Four strand core sutures have a better result with a lower tendon rupture rate than two strand core sutures. Other facts stated in literature are that the zone with the worst results was zone II, and Kleinert splints had better results than static splints. ${ }^{16-18}$

This study has several limitations: (1) The heterogeneity of the studies included is high. (2) Due to the limitation of studies, animal studies and in vitro studies are also included. This may contribute to the heterogeneity of the studies involved. However, to our knowledge, this study is the first to formulate a metaanalysis on this matter. It is hoped that this study might be influential for future study, conducting well-designed trials with a larger amount of samples.

\section{CONCLUSION}

Current systematic review and meta-analysis suggest that the 4-stranded cruciate repair technique has better strength and functional outcome than the modified Kessler repair technique. The Four-stranded Kessler technique is also proven to have better strength compared to the two-stranded Kessler technique.

\section{REFERENCES}

1. Hill R, Chan S. Flexor tendon injuries: a review. Int Musculoskelet Med. 2013 Jul 1; 35(2): 72-9.

2. Tang JB. Indications for primary flexor tendon repair. Tendon surgery of the hand. Philadelphia, Elsevier Saunders. 2012 Apr 23:81-7.

3. Dy CJ, Daluiski A, Do HT, HernandezSoria A, Marx R, Lyman S. The epidemiology of reoperation after flexor tendon repair. J Hand Surg Am. 2012 May 1;37(5):919-24.

4. de Jong JP, Nguyen JT, Sonnema AJ, Nguyen EC, Amadio PC, Moran SL. The incidence of acute traumatic tendon injuries in the hand and wrist: a 10-year population-based study. Clinics in orthopedic surgery. 2014 Jun;6(2):196.

5. Griffin M, Hindocha S, Jordan D, Saleh M, Khan W. An overview of the management of flexor tendon injuries. Open Orthop J. 2012; 6(Suppl 1:M3): 2835.

6. Hamzah SR, Fattah JH. The outcome of Flexor Tendon Repair based on the number of core suture, mechanism and zone of injury in Erbil. Zanco J Med Sci. 2018 Apr 1;22(1):1-7.

7. Starnes T, Saunders RJ, Means Jr KR. Clinical outcomes of zone II flexor tendon repair depending on mechanism of injury. The Journal of hand surgery. 2012 Dec 1;37(12):2532-40.

8. Rudge WB, James M. Flexor tendon injuries in the hand: a UK survey of repair techniques and suture materials-are we following the evidence? Int Sch Res Notices. 2014;2014:1-4.

9. Karjalainen $\mathrm{T}$, He M, Chong AK, Lim AY, Ryhanen J. An analysis of the pullout strength of 6 suture loop configurations in flexor tendons. J Hand Surg Am 2012; 37: 217-223.

10. Shaikh SA, Bawa A, Shahzad2 N, Yasmeen S, Afzal Beg MS. Comparison of Modified Kessler Technique versus Four Strand Cruciate Technique for Repair of Long Flexor Tendons of 
Fingers: A Randomized Controlled Trial. Surg Med Open Access J 2018; 1: 1-4.

11. Ranjan RK, Kumar M, Kumar S, Kumar $\mathrm{S}$, Subhash A. Flexor tendon injury of hand and its reconstruction. Int J Orthop Sci. 2019;5(1):87-9.

12. Barrie KA, Wolfe SW, Shean C, Shenbagamurthi D, Slade JF, Panjabi MM. A biomechanical comparison of multistrand flexor tendon repairs using an in situ testing model. J Hand Surg Am. 2000;25(3):499-506.

13. Dogramaci Y, Kalaci A, Sevinç TT, Esen E, Komurcu M, Yanat AN. Does strand configuration and number of purchase points affect the biomechanical behavior of a tendon repair? A biomechanical evaluation using different Kessler methods of flexor tendon repair. Hand. 2008;3(3):266-270.

14. Yalçin L, Demirci MS, Alp M, Akkin SM, Şener B, Koebke J. Biomechanical assessment of suture techniques used for tendon repair. Acta Orthop Traumatol Turc. 2011;45(6):453-457.

15. Dawood Alaa. Repair of Flexor Tendon Injuries by Four Strand Cruciate Technique Versus Two Strands Kessler Technique. Journal of Clinical Orthopaedics and Trauma. 2020;11(4):646-649.

16. Farzad M, Layeghi F, Asgari A, Ring DC, Karimlou M, Hosseini SA. A prospective randomized controlled trial of controlled passive mobilization vs. place and active hold exercises after zone 2 flexor tendon repair. Hand Surgery. 2014;19(01):53-9.

17. Silfverskiöld KL, May EJ, Oden A. Factors affecting results after flexor tendon repair in zone II: a multivariate prospective analysis. The Journal of hand surgery. 1993 Jul 1;18(4):654-62.

18. Güntürk ÖB, Kayalar M, Kaplan I, Uludağ A, Özaksar K, Keleşoğlu B. Results of 4strand modified Kessler core suture and epitendinous interlocking suture followed by modified Kleinert protocol for flexor tendon repairs in Zone 2. Acta Orthop Traumatol Turc. 2018 Sep 1;52(5):382-6. 